\title{
Analisis Penerapan Sistem Transaksi Non Tunai Dalam Pengelolaan Keuangan Daerah Pada Badan Keuangan Dan Aset Daerah Kabupaten Dairi
}

\section{Analysis of the Application of the Non-Cash Transaction System in Regional Financial Management at the Regional Finance and Assets Agency of Dairi Regency}

\author{
Fitri Rosalina N. Samosir1), Badaruddin ${ }^{2)}$ \& Nina Siti Salmaniah Siregar1)* \\ 1) Program Studi Magister Ilmu Administrasi Publik, Universitas Medan Area, Indonesia \\ 2) Program Studi Magister Studi Pembangunan, Fakultas Ilmu Sosial dan Ilmu Politik, \\ Universitas Sumatera Utara, Indonesia \\ Diterima: 11 Juli 2021; Disetujui: 15 Desember 2021; Dipublish: 1 Januari 2022
}

\begin{abstract}
Abstrak
Penelitian ini bertujuan untuk mengetahui, menganalisis dan faktor kendala dalam penerapan sistem transaksi non tunai dalam pengelolaan keuangan daerah pada Badan Keuangan dan Aset Daerah Kabupaten Dairi. Penelitian ini menggunakan metode deskriptif dengan pendekatan kualitatif, yaitu mengambil data-data yang berkaitan dengan permasalahan yang akan diteliti sehingga dapat diuraikan secara deskriptif, kualitatif dan komperhensif, yaitu menggambarkan kenyataan yang berlaku dan membahas permasalahan-permasalahan yang dikemukakan berkaitan dengan Penerapan Sistem Transaksi Non Tunai Dalam Pengelolaan Keuangan Daerah Pada Badan Keuangan dan Aset Daerah Kabupaten Dairi. Hasil penelitian didapatkan bahwa Badan Keuangan dan Aset Daerah Kabupaten Dairi belum sepenuhnya dapat menerapkan transaksi keuangan secara non tunai terhadap penerimaan pendapatan dan pengeluaran belanja sebagaimana ditetapkan dalam Perbup Dairi No. 43 Tahun 2020. Kendala yang dihadapi dalam penerapan atau implementasi transaksi belum dapat diatasi, karena memang terdapat banyak kondisi lapangan yang belum sesuai dengan pelaksanaan transaksi secara non tunai. Pegawai masih kurang mampu menangani proses transaksi secara non tunai, sementara program pelatihan belum memadai karena peralatan yang tersedia khususnya untuk melakukan praktek sangat terbatas.

Kata Kunci: Penerapan; Sistem Transaksi Non Tunai; Pengelolaan Keuangan Daerah; Badan Keuangan Dan Aset Daerah.
\end{abstract}

\begin{abstract}
Abstrak
This study aims to determine, analyze and factor constraints in the application of non-cash transaction systems in regional financial management at the Regional Finance and Assets Agency of Dairi Regency. This study uses a descriptive method with a qualitative approach, namely taking data related to the problems to be studied so that it can be described descriptively, qualitatively and comprehensively, which describes the prevailing reality and discusses the problems raised related to the Application of the Non-Cash Transaction System. In Regional Financial Management at the Regional Finance and Assets Agency of Dairi Regency. The results showed that the Regional Finance and Assets Agency of Dairi Regency has not been able to fully implement non-cash financial transactions on revenue receipts and expenditures as stipulated in Perbup Dairi No. 43 of 2020. The obstacles faced in implementing or implementing transactions have not been overcome, because there are indeed many field conditions that are not in accordance with the implementation of non-cash transactions. Employees are still not able to handle non-cash transaction processing, while the training program is inadequate because the available equipment, especially for practicing, is very limited. Keywords: Application; Non-Cash Transaction System; Regional Financial Management; Regional Finance and Assets Agency.
\end{abstract}

How to Cite: Samosir, F.R.N., Badaruddin, B., \& Siregar, N.S.S. (2022). Analisis Penerapan Sistem Transaksi Non Tunai Dalam Pengelolaan Keuangan Daerah Pada Badan Keuangan Dan Aset Daerah Kabupaten Dairi. PERSPEKTIF, 11 (1): 272-285

*Corresponding author:

E-mail: ninasitisalmaniah@staff.uma.ac.id ISSN 2085-0328 (Print) ISSN 2541-5913 (online) 


\section{PENDAHULUAN}

Keuangan Negara adalah semua hak dan kewajiban negara yang dapat dinilai dengan uang, serta segala sesuatu baik berupa uang maupun berupa barang yang dapat dijadikan milik negara berhubung dengan pelaksanaan hak dan kewajiban tersebut. Keuangan tersebut timbul sebagai bagian dari pembentukan pemerintahan negara yang berwewenang menyelenggarakan dan mewujudkan kesejahteraan umum.

Dalam pengelolaannya, keuangan negara harus dimanfaatkan sebesar-besarnya untuk kepentingan bangsa dan negara dengan cara pengelolaan yang efektif dan efisien sesuai dengan sumber dan peruntukan yang telah ditetapkan dalam anggaran pendapatan belanja, baik APBN maupun APBD. Dalam hal ini pemerintah harus berupaya agar segala bentuk penyimpangan yang terjadi pada transaksi penerimaan pendapatan dan transaksi pengeluaran pendapatan dapat dihindari, sehingga setiap rupiah dari pendapatan negara dapat memberikan manfaat bagi kesejahteraan masyarakat.

Penyelenggara urusan pemerintahan yang menjadi kewenangan daerah didanai dari dan atas beban Anggaran Pendapatan dan Belanja Daerah (APBD). Sementara itu, penyelenggara urusan pemerintahan yang menjadi kewenangan pemerintah pusat di daerah didanai dari dan atas beban Anggaran Pendapatan dan Belanja Negara (APBN). Administrasi pendanaan penyelenggara kedua jenis urusan pemerintahan tersebut dilakukan secara terpisah. Dalam pengelolaan keuangan daerah, kepala daerah adalah pemegang kekuasaan pengelolaa keuangan daerah. Dalam melaksanakan kekuasaannya, yang berupa perencanaan, pelaksanaan, penatausahaan, pelaporan dan pertanggungjawaban, serta pengawasan keuangan daerah kepada pejabat perangkat daerah. Pelimpahan ini didasarkan pada prinsip pemisahan kewenangan antara yang memerintahkan, menguji, dan yang menerima/mengeluarkan uang (Abdullah, 2015).

Umum diketahui bahwa penyimpangan penggunaan keuangan negara telah menjadi fonomena yang sering terjadi, terutama oleh pihak-pihak yang terlibat secara langsung dalam penanganan transaksinya. Terjadinya penyimpangan tersebut disebabkan adanya upaya dari oknum-oknum pejabat yang secara sengaja berupaya memperoleh manfaat secara tidak sah dari penggunaan keuangan negara untuk diri sendiri, yang sering disebut dengan korupsi. Permasalahan korupsi dengan segala bentuknya telah menjadi bagian dari budaya yang melekat pada perilaku pejabat, sehingga terdapat banyak pendapatan negara yang dinikmati oleh pejabat secara tidak sah. Oleh karena itu pemerintah telah berupaya membuat aturan hukum dalam penanganan transaksi keuangan, baik transaksi pendapatan maupun transaksi pengeluaran, yang tujuan utamanya adalah mempersempit ruang gerak dan celah hukum yang dapat digunakan oleh pejabat untuk melakukan penyimpangan dalam transaksi penggunaan anggaran (Poedjianto, et al., 2019; Hakim, et al., 2019; Silalahi et al., 2021; Ketike et al., 2021; Pasi et al., 2016; Rivan, \& Maksum, 2019).

Salah satu aturan hukum yang ditetapkan oleh pemerintah adalah Instruksi Presiden (Inpres) Nomor 10 Tahun 2016 tentang Aksi Pencegahan Dan Pemberantasan Korupsi Tahun 2016 dan Tahun 2017 yang memerintahkan agar setiap pendapatan dan belanja daerah harus secara bertahap dilakukan melalui transaksi non tunai, yang kemudian ditindaklanjuti dengan Surat Edaran Menteri Dalam Negeri Nomor 910/1867/SJ tentang Implementasi Transaksi Non Tunai pada Pemerintah Daerah Kabupaten/Kota. Surat edaran tersebut pada dasarnya juga bertujuan untuk mendorong pemerintah daerah kabupaten/kota untuk mengimplementasikan transaksi non tunai dalam setiap pemasukan maupun pengeluaran belanja.

Uang tunai adalah uang negara (berupa koin atau uang kertas) yang beredar di masyarakat umum dan digunakan sebagai alat pembayaran dalam aktivitas pertukaran barang dan jasa. Bentuk uang tunai yang kecil dan tidak dapat dibedakan berdasarkan kepemilikan serta mudah dipertukarkan menyebabkan uang tunai tersebut mudah diselewengkan atau disalahgunakan untuk kepentingan pribadi. Disamping itu, penggunaan uang tunai dalam transaksi penerimaan atau pembayaran dalam jumlah yang besar dapat mengundang berbagai bentuk kejahatan kriminal, sehingga sangat beresiko dalam bertransaksi. Oleh karena itu terdapat kebijakan agar setiap transaksi penerimaan pendapatan dan transaksi pembayaran belanja 
sedapat mungkin dilakukan secara non tunai, sehingga dalam bertransaksi tidak melibatkan uang tunai secara fisik.

Pembayaran non tunai adalah pembayaran yang dilakukan tanpa menggunakan uang tunai melainkan menggunakan cek, ATM, kartu kredit, kartu debit, dan lain-lain. Beberapa manfaat yang diperoleh dari transaksi non tunai itu, antara lain: mencegah peredaran uang palsu, penggelapan, transaksi illegal (korupsi), mewujudkan tertib administrasi pengelolaan kas, memudahkan penanganan uang persediaan secara ketat, serta kedisiplinan dalam melakukan pencatatan transaksi. Dengan demikian transaksi non tunai akan mencegah korupsi karena dengan transaksi tersebut akan jelas kepada siapa transaksi dilakukan sesuai dengan catatan transaksinya (catatan bank). Jika terdapat transaksi non tunai dengan pihak yang tidak berhak maka akan mudah ditelusuri sehingga para pihak yang berhubungan langsung dengan transaksi tersebut akan lebih hati-hati untuk tidak melakukan penyelewengan dana. Transaksi non tunai juga akan memperkecil jumlah persediaan uang tunai di bendahara pengeluaran yang berarti kesempatan untuk melakukan penyelewengan dana juga semakin kecil.

Tetapi ternyata penerapan transaksi non tunai khususnya di pemerintahan daerah belum sepenuhnya dilaksanakan. Misalnya di Kalimantan Timur, baru dua pemerintah daerah yang sudah melaksanakan program transaksi non tunai, yaitu Pemprov Kaltim dan Pemkot Samarinda (https://kaltimprov.go.id, diakses pada tanggal 15 Januari 2021). Di Jateng, transaksi non tunai baru diterapkan di tiga kota, yakni Kota Surakarta, Kota Salatiga dan Kota Magelang, namun demikian sebanyak 35 kabupaten/kota di Jawa Tengah telah bersepakat untuk segera menggunakan transaksi non-tunai dalam kegiatan operasionalnya (https://regional.kompas.com, diakses pada tanggal 15 Januari 2021. Sedangkan di lingkungan pemprov Sumatera Utara, transaksi non tunai telah dilaksanakan sejak tahun 2019 seiring dengan terbitnya Peraturan Gubernur Sumatera Utara No. 16 Tahun 2019 tentang Pedoman Pelaksanaan Transaksi Non Tunai.

Kabupaten Dairi merupakan salah satu daerah kabupaten yang terdapat di Propinsi
Sumatera Utara. Sebagai penjabaran lebih lanjut dari Intruksi Presiden dan Surat Edaran Menteri Dalam Negeri tentang transaksi non tunai, maka Bupati Dairi juga telah menerbitkan Peraturan Bupati Dairi No. 43 Tahun 2020 Tentang Pedoman Pelaksanaan Transaksi Non Tunai di Lingkungan Pemerintah Kabupaten Dairi. Perbup tersebut ditujukan kepada Sekdakab dan para asistennya, serta kepada para kepala SKPD yang salah satunya adalah Badan Keuangan dan Aset Daerah Kabupaten Dairi, agar melakukan transaksi melalui mekanisme transaksi non tunai untuk seluruh pendapatan pajak dan retribusi serta seluruh transaksi pengeluaran belanja tidak langsung dan belanja langsung dengan batasan nilai pengadaan di atas Rp. 10.000.000. Instruksi tersebut juga menghimbau agar pihak ketiga membuka rekening di Bank Sumut sebagai bank yang mengelola kas daerah Kabupaten Dairi.

Berdasarkan Peraturan Bupati Dairi No. 43 Tahun 2020 Tentang Pedoman Pelaksanaan Transaksi Non Tunai di Lingkungan Pemerintah Kabupaten Dairi pada Pasal 5 maka:

(1) Implementasi transaksi non tunai di lingkungan Pemerintah Kabupaten Dairi meliputi:

a. penerimaan daerah yang dilakukan oleh bendahara penerimaan/bendahara penerimaan pembantu; dan

b. pengeluaran daerah yang dilakukan oleh bendahara pengeluaran/bendahara pengeluaran pembantu.

(2) Implementasi transaksi non tunai ini termasuk Perusahaan Daerah dan Badan Layanan Umum Daerah.

(3) Transaksi penerimaan dan pengeluaran daerah non tunai diakomodir melalui aplikasi pengelolaan keuangan daerah dan layanan yang disediakan oleh perbankan secara online.

Adapun pelaksanaan berbagai pembayaran secara transaksi non tunai diwujudkan sebagai salah satu upaya pembenahan tata kelola keuangan di Pemerintah Kabupaten Dairi yang dimplementasikan oleh Bupati Dairi Peraturan Bupati Dairi No. 43 Tahun 2020 Tentang Pedoman Pelaksanaan Transaksi Non Tunai di Lingkungan Pemerintah Kabupaten Dairi 
dimana di lingkungan pemerintah Kabupaten Dairi sudah tidak lagi melakukan transakasi secara tunai untuk segala penerimaan maupun pengeluaran APBD melainkan hanya pelaksanaan transaksi non tunai dan diterapkan melalui layanan Cash Management System (CMS) dari PT Bank Sumut untuk setiap transaksi pendapatan maupun belanja pemerintah daerah termasuk transaksi terhadap pihak ketiga yang seringkali menjadi temuan pemeriksaan serta unsur dari tindak penyelewengan keuangan/korupsi. penyelenggaraan

Hasil audit BPK RI Perwakilan Sumatera Utara untuk Pemerintah Daerah Dairi Tahun 2020 adalah Wajar Tanpa Pengecualian (WTP), prestasi ini diterima Pemerintah Daerah Kabupaten Dairi sejak 5 tahun silam. Hal ini yang mendorong Pemerintah Daerah Kabupaten Dairi untuk menjaga prestasi baik ini dengan melaksanakan Program Transaksi Non Tunai. Masih buruknya sistem pengendalian internal dalam tata kelola keuangan di Lingkungan Pemerintah Kabupaten Dairi yaitu kendala Sumber Daya Manusia (SDM), kendala pada bank dan kendala keterbatasan sarana dan prasarana yang kurang memadai seperti listrik, koneksi internet, dan ketersediaan data center. Dalam mengatasi tata kelola kuangan daerah yang baik sangatlah dibutuhkan di lingkungan pemerintahan Kabupaten Dairi.

Beberapa penelitian terdahulu yang relevan adalah Rachmad Saleh Solin (2018) bahwa Pemko Subulussalam belum sepenuhnya dapat menerapkan transaksi keuangan secara non tunai terhadap penerimaan pendapatan dan pengeluaran belanja sebagaimana ditetapkan dalam kebijakan pada Perwal Subulussalam No. 121 Tahun 2017. Kendala yang dihadapi dalam implementasi Perwal Subulussalam No. 121 Tahun 2017 belum dapat diatasi, karena memang terdapat banyak kondisi lapangan yang belum sesuai dengan pelaksanaan transaksi secara non tunai. Angelina Pelealu, bahwa Dinas Kota Bitung telah menerapkan sistem transaksi nontunai secara bertahap APBD berdasarkan Surat Edaran Menteri Dalam Negeri Nomor 910/1866 / SJ. Itu Kendala yang dihadapi adalah proses administrasi terkadang terhambat, sosialisasi proses, penerapannya hingga penerimaan retribusi dengan nilai nominal kecil. Nikesari
Puji Utari dan Roy Valiant Salomo (2017) Pelaksanaan mekanisme non tunai yang dilakukan sudah berdasarkan good governance tetapi belum sempurna karena yang dilakukan oleh Pemerintah Provisi DKI Jakarta masih dalam tahap pengembangan sehingga tetap masih perlunya dukungan pihak-pihak yang membantu Pemprov DKI tidak hanya dari sektor perbankan melainkan Dari stakeholder/vendor/pihak ketiga serta masyarakat turut mensukseskan keberhasilan dalam implementasi non tunai ini.

Kadek Ayu Dian Purnamasari Ningrat Dartawan (2018) bahwa penerapan transaksi non tunai di Sekretariat DPRD Provinsi Bali sudah mulai dilaksanakan pada tanggal 1 Januari 2018 oleh seluruh Pegawai Sekretariat DPRD Provinsi Bali serta seluruh Anggota DPRD Provinsi Bali. Kebijakan ini sudah dilaksanakan sesuai dengan Instruksi Gubernur Bali Nomor 5961 Tahun 2017 Tentang Pelaksanaan Transaksi Non Tunai (Non Cash). Lidanna Dian Kurnia (2020) bahwa penerapan transaksi non tunai dalam pengelolaan keuangan daerah pada sekretariat daerah Kota Metro Provinsi Lampung memberikan banyak manfaat yaitu transaksi menjadi sangat efisien dan juga efektif. Haryono (2020) bahwa Secara keseluruhan pelaksanaan Transaksi Non Tunai di Pemerintah Daerah Kabupaten Landak berjalan dengan lancar dan dapat meningkatkan transparansi serta akuntabilitas pengelolaan keuangan daerah.

Suluh Hendrawan (2019) Pemerintah Kabupaten Jombang. Akuntabilitas, transparansi serta tertib administrasi sudah berhasil dicapai dalam implementasitransaksi non-tunai. Akan tetapi efisiensi dari penggunaan anggaran belum mampu tercapai. Namun demikian, pada tataran strategi, sistem dan struktur sudah berjalan dengan baik. Faktor kemampuan,sumber daya manusia serta gaya kepemimpinan yang perlu diperhatikan secara berkelanjutan agardalam keberhasilan strategi pencapaian tata kelola pemerintahan yang baik. Adam Al Kautsar (2021) Penerapan Sistem Transaksi Non Tunai Dalam Pelaksanaan Belanja Langsung Di Dinas Sosial Kota Tangerang, memiliki kelebihan yaitu efektifitas serta efisiensi waktu serta meminimalisir praktik pungli ataupun korupsi pada kegiatan belanja langsung.Dan juga memiliki kendala dalam pelaksanaannya yaitu masih seringnya terjadi jaringan error. Selly 
Septiani (2019) Penerapan Transaksi Non Tunai Dalam Pelaksananan Belanja Pemerintah Daerah Untuk Mewujuadnkan Prinsoip Good Governane penerapan transaksi non tunai ini dirasakan dapat meningkatkan perwujudan prinsip good governance terutama prinsip akuntabilitas, transparansi, efektivitas dan efisiensi. Dengan adanya penerapan transaksi non tunai dalam pelaksanaan belanja pemerintah dapat menekan tingkat penyelewengan terutama korupsi.

Berdasarkan latar belakang dan penelitian yang relevan, maka penelitian ini bertujuan: Untuk mengetahui, menganalisis dan faktor kendala dalam penerapan sistem transaksi non tunai dalam pengelolaan keuangan daerah pada Badan Keuangan dan Aset Daerah Kabupaten Dairi.

\section{METODE PENELITIAN}

Penelitian ini menggunakan metode deskriptif dengan pendekatan kualitatif, yaitu mengambil data-data yang berkaitan dengan permasalahan yang akan diteliti sehingga dapat diuraikan secara deskriptif, kualitatif dan komperhensif, yaitu menggambarkan kenyataan yang berlaku dan membahas permasalahan-permasalahan yang dikemukakan berkaitan dengan Penerapan Sistem Transaksi Non Tunai Dalam Pengelolaan Keuangan Daerah Pada Badan Keuangan dan Aset Daerah Kabupaten Dairi. Penelitian ini dipaparkan secara deskriptif dengan metode pendekatan yuridis administrasi publik.

Penelitian deskriptif adalah prosedur yang bertujuan membuat pencandraan secara sistematis, faktual, dan akurat mengenai faktafakta dan sifat-sifat populasi atau fenomena keadaan yang sedang terjadi. Digunakannya metode deskriptif ini, karena peneliti ingin memperoleh hasil yang benar-benar sesuai dengan fakta yang ada dan berkembang.Untuk pendekatan yuridis dalam penelitian ini dimaksudkan untuk membahas Penerapan Sistem Transaksi Non Tunai Dalam Pengelolaan Keuangan Daerah Pada Badan Keuangan dan Aset Daerah Kabupaten Dairi.

Penelitian kualitatif tidak dimaksudkan untuk membuat generalisasi dari hasil penelitiannya. Menurut Bagong Suyatno (2015) bahwa Informan penelitian meliputi beberapa macam, yaitu: 1) informan kunci merupakan mereka yang mengetahui dan memiliki berbagai informasi pokok yang diperlukan dalam penelitian, 2) informan utama merupakan mereka yang terlibat langsung dalam interaksi sosial yang diteliti, 3) informan tambahan merupakan mereka yang dapat memberikan informasi walaupun tidak langsung terlibat dalam interaksi sosial yang diteliti.

Dalam penelitian ini, penulis menggunakan informan kunci yaitu: Sekretaris Badan Keuangan dan Aset Daerah Kabupaten Dairi; Kasubbag Keuangan dan Aset Badan Keuangan dan Aset Daerah Kabupaten Dairi; Bendahara Penerimaan Badan Keuangan dan Aset Daerah Kabupaten Dairi.

Teknik pengumpulan data adalah langkah penting dalam penelitian ilmiah karena data yang dihasilkan digunakan untuk memecahkan masalah yang ada.Alat pengumpul data berfungsi untukmengumpulkan data-data di lapangan yang diperlukan dalam kegiatan penelitian. Pengumpulan data dalam penelitian ini menggunakan penelitian lapangan (field research), yaitu dengan mendatangi secara langsung lokasi penelitian dan mengamati kejadian atau keadaan sebenarnya.

Adapun teknik pengumpulan data pada penelitian ini antara lain : Pengumpulan Data Primer, Yaitu perolehan data melalui kegiatan penulis langsung ke lokasi penelitian untuk mendapat data yang lengkap dan berkaitan dengan masalah yang diteliti, yaitu: Wawancara (interview) merupakan salah satu metode pengumpulan data dengan jalan komunikasi, yakni melalui kontak atau hubungan pribadi antara peneliti dengan sumber data (informan). Komunikasi tersebut dapat dilakukan secara langsung dan tidak langsung. Dalam penelitian ini komunikasi dilakukan secara langsung, wawancara dilakukan dengan cara "face to face" artinya peneliti berhadapan langsung dengan informan untuk menanyakan secara lisan hal-hal yang berkaitan dengan fokus penelitian dan peneliti mencatat jawaban dari informan.

Pengamatan (observasi) adalah pengumpulan data untuk menjawab masalah penelitian dengan cara melakukan pengamatan yakni mengamati gejala yang diteliti secara langsung. Teknik pengamatan ini memungkinkan peneliti melihat dan mengamati sendiri, kemudian mencatat perilaku dan kejadian sebagaimana yang terjadi pada keadaan sebenarnya. Dalam penelitian ini, peneliti melakukan pengamatan terhadap 
Penerapan Sistem Transaksi Non Tunai Dalam Pengelolaan Keuangan Daerah Pada Badan Keuangan dan Aset Daerah Kabupaten Dairi.

Pengumpulan Data Sekunder: Studi kepustakaan, yaitu dengan mengumpulkan data dan informasi melalui literatur yang relevan dengan judul penelitian seperti bukubuku, artikel dan makalah yang memiliki relevansi dengan masalah yang diteliti. Studi dokumentasi, yaitu suatu teknik pengumpulan data dari dokumen atau arsip-arsip termasuk internet yang sesuai dengan masalah yang diteliti.

Menurut Sugiyono (2017) bahwa "Analsiis data dalam penelitian kualitatif, dilakukan pada saat pengumpulan data berlangsung, dan setelah selesai pengumpulan data dalam periode tertentu".

Analisis data yang dilakukan secara deskriptif kualitatif, yaitu mengambil data-data yang berkaitan dengan permasalahan yang akan diteliti sehingga dapat diuraikan secara deskriptif, kualitatif dan komperhensif, yaitu menggambarkankenyataan yang berlaku dan masih ada kaitannya dengan aspek-aspek hukum yang berlaku. Aktivitas dalam analisis data kualitatif dilakukan secara interaktif dan berlangsung secara terus-menerus sampai tuntas, sehingga datanya sudah jenuh. Sejalan dengan analisis yang dimaksud, maka dalam penelitian ini upaya penggambaran secara sistematis, aktual dan akurat mengenai Penerapan Sistem Transaksi Non Tunai Dalam Pengelolaan Keuangan Daerah Pada Badan Keuangan dan Aset Daerah Kabupaten Dairi.

\section{HASIL DAN PEMBAHASAN}

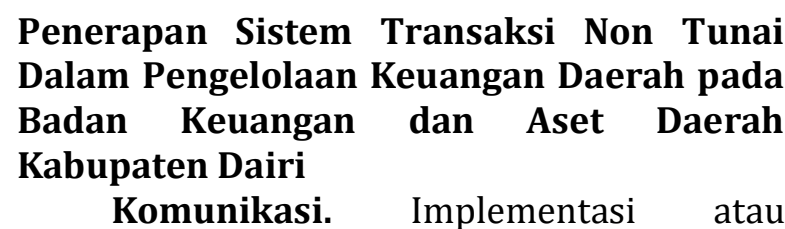
penerapan suatu kebijakan harus didahului dengan sosialisasi tentang kebijakan kepada semua pihak yang berkaitan. Sosialisasi tersebut dilaksanakan melalui serangkaian proses komunikasi, yaitu penyampaian informasi tentang isi kebijakan, baik komunikasi langsung maupun komunikasi melalui media. Komunikasi kebijakan dikatakan berhasil apabila disampaikan melalui saluran komunikasi yang tepat (transmisi), maksud kebijakan disampaikan secara jelas, serta terdapat konsistensi atas kebijakan yang disampaikan dalam arti tidak berubah-ubah. Berikut ini akan dibahas mengenai bagaimana proses komunikasi implementasi kebijakan transaksi non tunai sebagaimana diatur dalam Perbup Dairi No. 43 Tahun 2020, yang terdiri dari transmisi, konsistensi dan kejelasan.

Transmisi. Penyampaian kebijakan transaksi non tunai sebagaimana dalam Perbup Dairi No. 43 Tahun 2020 harus dilakukan melalui jenis komunikasi yang mampu menyampaikan maksud kebijakan secara tepat kepada pihak yang terkait, khususnya kepada para implementor, yang dalam hal ini adalah pegawai Badan Keuangan dan Aset Daerah Kabupaten Dairi. Pada umumnya penyampaian informasi tersebut dapat dilakukan melalui atasan maupun melalui media komunikasi, seperti media cetak dan media elektronik.

Dari hasil wawancara di lapangan, dapat disimpulkan bahwa peranan atasan untuk menyampaikan informasi tentang sistem transaksi non tunai telah dilaksanakan dengan baik. Atasan melakukan pertemuan untuk dapat menyampaikan informasi tersebut kepada semua pihak, yang kemudian dilanjutkan dengan sesi pembahasan terhadap segala hal yang diperlukan untuk persiapan penerapan peraturan. Dengan demikian peranan atasan menyampaikan informasi telah dilaksanakan dengan baik dalam rangka proses implementasi transaksi non tunai di Kabupaten Dairi.

Menurut Edward III dalam Widodo (2010), komunikasi diartikan sebagai proses penyampaian informasi komunikator kepada komunikan. Informasi mengenai kebijakan publik menurut Edward III dalam Widodo (2010) perlu disampaikan kepada pelaku kebijakan agar para pelaku kebijakan dapat mengetahui apa yang harus mereka persiapkan dan lakukan untuk menjalankan kebijakan tersebut sehingga tujuan dan sasaran kebijakan dapat dicapai sesuai dengan yang diharapakan.

Setelah informasi tentang kebijakan transaksi non tunai diketahui oleh implementor maka informasi tersebut lebih lanjut harus dipelajari dengan mendiskusikannya dalam suatu forum, sehingga dapat diketahui hal-hal apa yang perlu dilakukan untuk menerapkan kebijakan tersebut. Kemudian agar implementasi menjadi efektif, maka mereka yang menanggungjawabnya adalah untuk 
mengimplementasikan sebuah program mesti tahu apa yang seharusnya mereka kerjakan.

Komunikasi juga harus dilakukan kepada pihak eksternal yang berhubungan dengan transaksi, yaitu rekanan atau penyedian barang dan jasa, bank, wajib pajak serta pihak lain yang mempunyai hubungan transaksi dengan Pemda Dairi. Komunikasi untuk sosialisasi kepada masyarakat umum harus dilakukan dengan tepat, sehingga penyampaian informasi tentang transaksi non tunai dapat dilakukan secara efektif.

Dari hasil wawancara, dapat disimpulkan bahwa sosialisasi tentang sistem transaksi non tunai kepada pihak eksternal yang terkait dengan transaksi dilakukan melalui beberapa cara, yaitu melalui media massa dan media reklame, membuat pertemuan khusus dengan mengundang pihak eksternal. Sosialisasi juga dilakukan kepada pihak terkait dengan memberitahukan secara langsung pada saat transaksi akan segera dilakukan. Dengan demikian sosialisasi dalam rangka proses implementasi sistem transaksi non tunai kepada pihak eksternal telah dilakukan dengan baik di Kabupaten Dairi.

Implementasi kebijakan dalam menemukan kendala di lapangan karena situasi yang tidak sikron dengan kebijakan, sehingga perlu komunikasi yang baik antara petugas dengan atasan dalam mengatasi kendala.

Dari hasil wawancara di lapangan, dapat disimpulkan bahwa jalur komunikasi untuk meminta arahan atas kendala yang dihadapi dalam implemenentasi transaksi non tunai dapat dilakukan dengan cara menghadap atasan secara langsung, atau membuat pemberitahuan melalui telepon. Disamping itu, kendala yang dihadapi juga dapat dilaporkan dalam rapat koordinasi yang sering dilakukan untuk memecahkan berbagai masalah yang dihadapi. Dengan demikian proses implementasi sistem transaksinon tunai telah didukung dengan jalur komunikasi yang baik antara atasan dengan bawahan untuk melaporkan setiap kendala yang dihadapi dalam pelaksanaan transaksi non tunai.

Kejelasan. Komunikasi dalam implementasi (penerapan) sistem transaksi non tunai harus dapat memberi kejelasan tentang maksud dari kebijakan, sehingga tidak menimbulkan kekeliruan dalam penerapannya. Implementor juga harus dapat memperoleh kejelasan untuk hal-hal yang belum dimengerti sehubungan dengan maksud dari kebijakan yang ditetapkan.

Dari hasil wawancara, dapat disimpulkan bahwa proses penyampaian kebijakan sistem transaksi non tunai telah dilakukan dengan baik, karena komunikator yang menyampaikan informasi menguasai atau mempunyai pemahaman yang baik tentang kebijakan yang akan diterapkan sehingga cukup berkompeten untuk memberi penjelasan. Disamping itu, penyampaian juga disertai dengan pemberian cetakan dari Perbup Dairi No. 43 Tahun 2020 secara lengkap. Dengan demikian, proses yang dilakukan untuk menyampaikan informasi kebijakan telah berhasil untuk memberi infirmasi yang jelas mengenai kebijakan transaksi non tunai sebagaimana maksud dari pembuat kebijakan.

Kemampuan atasan memberi penjelasan juga sangat penting untuk menjamin bahwa pegawai dapat menambah pemahamannya untuk hal-hal yang tidak dimengerti dalam sistem transaksi non tunai sebagaimana diatur dalam Perbup Dairi No. 43 Tahun 2020. Hal tersebut akan menjamin bahwa semua hal yang tidak dimengerti dapat memperoleh kejelasan, sehingga lebih mudah dalam penerapannya.

Dari hasil wawancara di atas dapat disimpulkan bahwa atasan pada instansi mempunyai kemampuan yang baik dalam memberi penjelasan terhadap hal-hal yang kurang dipahami oleh pegawai sehubungan dengan kebijakan yang akan diimplementasikan. Dengan demikian kemampuan atasan memberi penjelasan kepada bawahan sesuai dengan maksuk pembuat kebijakan telah cukup mendukung proses implementasi sistem transaksi non tunai.

Konsistensi. Yang dimaksud dengan konsistensi bahwa implementor mampu memahami kebijakan secara konsisten sebagaimana maksud pembuat kebijakan, dan kebijakan tersebut dapat diterapkan secara konsisten sebagaimana seharusnya menurut kebijakan.

Dari hasil wawancara di atas dapat dapat dijelaskan bahwa setiap pegawai telah mampu memahami peraturan tentang sistem transaksi non tunai konsisten sebagaimana maksud dari kebijakan tersebut. Perbedaan penafsiran sebagai akibat kurangnya pemahaman selalu dapat diatasi dengan melalui diskusi yang baik, karena pada dasarnya para pegawai sama- 
sama mempunyai keinginan yang kuat untuk menyatukan pemahaman terhadap kebijakan tersebut. Dengan demikian, pemahaman pegawai sebagai implementor telah sesuai dengan maksud pembuat kebijakan sistem transaksi non tunai dalam Perbup Dairi No. 43 Tahun 2020.

Tahap paling penting dari implementasi adalah pelaksanaan dilapangan, dimana tahap tersebut sering mendapat kendala karena kondisi lapangan yang kurang sesuai atau kurang mendukung dengan pelaksanaan sistem transaksi non tunai. Dalam hal ini atasan harus dapat memberi penyelesaian yang tepat agar kebijakan benar-benar dapat diterapkan.

Dari hasil wawancara di atas dapat disimpulkan bahwa kondisi di lapangan yang dibutuhkan dalam sistem transaksi non tunai belum sesuai dengan pelaksnaaan transaksi non tunai, sehingga terdapat banyak kendala dalam penerapannya. Penyelesaian terhadap faktor kendala tersebut belum dapat dilakukan dengan segera, sehingga menurut hasil wawancara hanya implementasi harus dilakukan secara bertahap tanpa harus mengganggu proses transaksi keuangan. Dengan demikian dapat dijelaskan bahwa implementasi terhadap sistem transaksi non tunai belum dapat dilakukan secara konsisten dalam semua transaksi keuangan karena faktor pendukung yang kurang memadai.

Sumber Daya. Implementasi atau penerapan suatu kebijakan harus didukung oleh ketersediaan sumber daya, yaitu segala sesuatu yang terdapat pada organisasi, baik sumberdaya fisik maupun sumber daya non fisik. Sering terjadi bahwa sumber daya yang tidak tersedia menyebabkan implementasi tidak dapat dilakukan sehingga maksud dari pembuat kebijakan menjadi tidak dapat dicapai sebagaimana mestinya.

Edward III dalam Widodo (2010) mengemukakan bahwa faktor sumber daya mempunyai peranan penting dalam implementasi kebijakan. Menurut Edward III dalam Widodo (2010) bahwa sumberdaya tersebut meliputi sumberdaya manusia, sumberdaya anggaran, dan sumberdaya peralatan dan sumberdaya kewenangan.

Penerapan sistem transaksi non tunai juga membutuhkan dukungan dari berbagai jenis sumber daya, khususnya sumber daya yang terdapat pada instansi pemerinrah daerah. Indikator yang digunakan untuk mengetahui dukungan sumber daya adalah: kompetensi SDM (pegawai), program pelatihan SDM, sistem informasi, dan ketersediaan finansial.

Kompetensi SDM untuk implementasi sistem transaksi non tunai merujuk pada keahlian dan keterampilan yang dimiliki oleh SDM untuk melakukan transaksi secara non tunai. Kompetensi tersebut meliputi kemampuan bekerjasama dengan semua pihak, serta pengetahuan mengenai berbagai jenis transaksi keuangan, khususnya transaksi non tunai.

Sesuai dengan wawancara di atas dapat dijelaskan bahwa pegawai yang menangani transaksi keuangan telah memiliki kompetensi dalam menjalin kerjasama dengan semua pihak yang terkait dengan transaksi non tunai, sehingga semua informasi yang dibutuhkan dalam pelaksanaan transaksi tersebut dapat diperoleh. Dengan demikian dapat disimpulkan kemampuan bekerjasama pegawai telah cukup mendukung dalam proses implementasi sistem transaksi non tunai di Kabupaten Dairi.

Pengetahuan pegawai yang luas mengenai berbagai jenis transaksi sangat diperlukan untuk memperlancar implementasi sistem transaksi non tunai. Pengetahuan tersebut biasanya dapat diperoleh dari pengalaman kerja dan juga dari proses belajar.

Sumberdaya manusia merupakan salah satu variabel yang mempengaruhi keberhasilan pelaksanaan kebijakan. Edward III dalam Widodo (2010) menyatakan bahwa "probably the most essential resources in implementing policy is staff". Edward III dalam Widodo (2010) menambahkan "no matter how clear and consistent implementation order are and no matter accurately they are transmitted, if personnel responsible for carrying out policies lack the resources to do an effective job, implementing will not effective".

Berdasarkan uraian di atas dapat dijelaskan bahwa pegawai telah mempunyai pengetahuan yang luas mengenai berbagai jenis transaksi keuangan, yang diperoleh melalui pencarian informasi maupun dengan cara belajar dari teman seprofesi. Dengan demikian kompetensi pegawai dari segi pengetahuan mengenai berbagai jenis transaksi telah cukup mendukung dalam proses implementasi sistem transaksi non tunai. 
Selanjutnya kompetensi pegawai dalam penanganan proses transaksi secara non tunai juga sangat perlu dan merupakan kompetensi inti yang paling diperlukan dalam penerapan sistem transaksi non tunai.

Pegawai pada Penda Dairi masih kurang mampu menangani proses transaksi secara tunai, tetapi mereka telah berupaya untuk meningkatkan kemampuannya dalam bertransaksi secara non tunai. Dengan demikian bahwa kompetensi pegawai dalam penanganan proses transaksi secara non tunai belum memadai untuk mendukung implementasi sistem transaksi non tunai.

Sistem informasi berperan penting dalam setiap transaksi, baik transaksi tunai maupun transaksi non tunai. Sistem informasi tersebut menyediakan data jenis transaksi dan besarnya transaksi, yang kemudian dapat digunakan untuk mengetahui apakah transaksi harus dilakukan secara tunai atau non tunai, karena pada dasarnya kebijakan dalam sistem transaksi non tunai sebagaimana diatur dalam Perbup Dairi No. 43 Tahun 2020 semakin besar jumlah transaksi maka pembayarannya harus dilakukan secara non tunai. Oleh karena itu, penerapan transaksi tersebut harus didukung dengan sistem informasi yang baik pada instansi.

Sistem informasi pada Badan Keuangan dan Aset Daerah Kabupaten Dairi belum dapat mendukung implementasi Perbup Dairi No. 43 Tahun 2020. Sistem informasi tidak dapat menyediakan lebih awal informasi mengenai berapa jumlah pembayaran atas suatu jenis belanja, sehingga baru diketahui setelah adanya realisasi belanja. Demikian juga dengan penerimaan pendapatan tidak dapat diketahui lebih awal mengenai jumlah yang diterima, sehingga persiapan transaksi secara non tunai, khususnya dengan perorangan sulit dilaksanakan.

Sistem informasi juga diperlukan untuk menangani transaksi penerimaan dari pembayar pajak perorangan atau masyarakat umum, seperti pelayanan pembayaran pajak kenderaan serta pajak bumi dan bangunan.

Wajib pajak perorangan, seperti pajak kenderaan dan pajak bumi dan bangunan masih dilakukan secara konvensional, dimana masyarakat harus datang ke kantor pembayaran pajak, kemudian mengikuti prosedur yang telah ditetapkan, mulai dari pengisian formulir hingga pembayaran ke loket pembayaran secara tunai. Dengan demikian dapat disimpulkan bahwa sistem transaksi non tunai belum dapat dimplementasikan dalam pelayanan pembayaran pajak perorangan dari masyarakat umum.

Program Pelatihan Pegawai. Implementasi kebijakan dalam sistem transaksi non tunai membutuhkan pegawai yang benarbenar mampu memahami proses transaksi secara non tunai. Penggunaan peralatan transaksi non tunai sering tidak sederhana dan membutuhkan keahlian tersendiri, sehingga pelatihan pegawai harus dilakukan. Wawancara tentang program pelatihan pegawai Badan Keuangan dan Aset Daerah Kabupaten Dairi diuraikan berikut ini.

Program pelatihan kepada pegawai telah dilaksanakan. Tetapi program tersebut belum memadai karena peralatan yang tersedia khususnya untuk melakukan praktek sangat terbatas. Menurut informan bahwa program pelatihan masih perlu pengembangan sehingga benar-benar dapat menghasilkan pegawai yang terampil sesuai dengan kebutuhan. Dengan demikian dapat disimpulkan bahwa program pelatihan yang dilaksanakan masih kurang memadai untuk mendukung implementasi sistem transaksi non tunai.

Ketersediaan Dana. Sumber daya finansial atau ketersediaan dana mempunyai peranan penting dalam implementasi kebijakan. Dana tersebut dibutuhkan untuk memenuhi kebutuhan barang dan jasa yang diperlukan dalam mendukung proses implementasi. Edward III dalam Widodo (2010) menyatakan dalam kesimpulan studinya "budgetary limitation, and citizen opposition limit the acquisition of adequate facilities. This is turn limit the quality of service that implementor can be provide to public". Menurut Edward III, terbatasnya anggaran yang tersedia menyebabkan kualitas pelayanan yang seharusnya diberikan kepada masyarakat juga terbatas.

Edward III dalam Widodo (2010) menyatakan bahwa "new towns studies suggest that the limited supply of federal incentives was a major contributor to the failure of the program". Menurut Edward III, terbatasnya insentif yang diberikan kepada implementor merupakan penyebab utama gagalnya pelaksanaan program.

Edward III dalam Widodo (2010) menyimpulkan bahwa terbatasnya sumber 
daya anggaran akan mempengaruhi keberhasilan pelaksanaan kebijakan. Disamping program tidak bisa dilaksanakan dengan optimal, keterbatasan anggaran menyebabkan disposisi para pelaku kebijakan rendah. Wawancara tentang ketersediaan sumber daya finansial diuraikan berikut ini.

Sumber daya finansial yang dibutuhkan dalam proses implementasi sistem transaksi non tunai belum dapat tersedia sesuai kebutuhan, karena jumlah kebutuhan cukup besar sehingga tidak dapat dipenuhi dalam satu tahun anggaran. Penyediaan anggaran untuk implementasi kebijakan tersebut akan dilakukan secara bertahap sehingga tidak membebani anggaran tahunan.

Disposisi. Disposisi merupakan gambaran atas sifat pribadi yang terdapat pada implementor. Semakin baik sifat-sifat pribadi maka proses implementasi kebijakan akan semakin lancar. Disposisi menurut Edward III dalam Widodo (2010) dikatakan sebagai kemauan, keinginan dan kecenderungan para perlaku kebijakan untuk melaksanakan kebijakan tadi secara sungguh sungguh sehingga apa yang menjadi tujuan kebijakan dapat diwujudkan. Edward III dalam Widodo (2010) mengatakan bahwa jika implementasi kebijakan ingin berhasil secara efektif dan efisien, para pelaksana (implementors) tidak hanya mengetahui apa yang harus dilakukan dan mempunyai kemampuan untuk melakukan kebijakan tersebut, tetapi mereka juga harus mempunyai kamauan untuk melaksanakan kebijakan tersebut.

Demikian juga dalam proses implementasi sistem transaksi non tunai membutuhkan implementor yang benar-benar dapat menunjukkan sifat-sifat yang terkendali dalam arti dapat mendukung dilakukannya proses implementasi. Sifat-sifat pribadi yang penulis identifikasi untuk mengetahui disposisi pegawai dalam penelitian ini adalah tanggung jawab, komitmen, dan sifat kerja keras. Ketiga sifat tersebut sangat berkaitan erat dengan keberhasilan penerapan kebijakan yang masih baru, sebagai mana diuraikan barikut ini:

Tanggungjawab merupakan sifat pribadi bagaimana seseorang merasa berkewajiban untuk mewujudkan suatu tujuan, yang dalam penelitian ini adalah mewujudkan penerapan transaksi non tunai sebagaimana diatur dalam Perbup Dairi No. 43 Tahun 2020. Pegawai yang merasa bertanggungjawab akan menyadari bahwa kegagalan atau keberhasilan implementasi merupakan gambaran dari keberhasilannya.

Pegawai merasa bertanggungjawab untuk mewujudkan pelaksanaan kebijakan transaksi non tunai. Terdapat tingkat kesadaran yang tinggi bahwa implementasi kebijakan tersebut merupakan tanggungjawab bersama yang harus dilaksanakan sebagai satu kesatuan, dimana kegagalan atau keberhasilan implementasi merupakan gambaran dari tingkat prestasi kerja. Dengan demikian sifat bertanggungjawab pegawai telah mendukung proses implementasi sistem transaksi non tunai di Kabupaten Dairi.

Suatu tanggungjawab dapat ditunjukkan dari segala usaha yang dilakukan untuk menyelesaikan pekerjaan secara tepat waktu.

Pegawai menunjukkan tanggungjawab yang tinggi untuk menyelesaikan semua pekerjaan yang berhubungan dengan proses implementasi kebijakan transaksi non tunai, sehingga mereka berusaha menyelesaikan pekerjaan tersebut sesuai dengan waktu yang ditetapkan. Dengan demikian sifat bertanggungjawab terhadap pekerjaan yang ditunjukkan oleh pegawai telah mendukung proses implementasi sistem transaksi non tunai.

Komitmen sebagai sifat implementor merupakan keinginan atau kemauan untuk melaksanakan kebijakan transaksi penerimnaan pendapatan dan pembayaran belanja asecara non tunai sebagaimana dinyatakan dalam Perbup Dairi No. 43 Tahun 2020. Kesediaan dengan kemauan yang kuat serta kesediaan untuk mengutamakan pekerjaan dibanding urusan pribadi adalah penting untuk mewujudkan kebijakan yang ditetapkan.

Pegawai pada Badan Keuangan dan Aset Daerah Kabupaten Dairi mempunyai keinginan dan kemauan (komitmen) yang kuat untuk menerapkan transaksi penerimaan dan pengeluaran belanja secara non tunai sebagaimana ditetapkan dalam Perbup Dairi No. 43 Tahun 2020, tetapi ketersediaan fasilitas pendukung belum cukup memadai, sehingga penerapannya belum dapat benar-benar dilaksanakan pada semua jenis transaksi, khususnya transaksi non tunai pada penerimaan pendapatan. Tetapi adanya komitmen yang kuat dari pegawai telah cukup 
mendukung proses implementasi sistem transaksi non tunai.

Kesediaan pegawai untuk mengutamakan pekerjaan sangat penting untuk dapat secara berhasil mengatasi berbagai kendala dalam pelaksanaan transaksi non tunai.

Pegawai belum dapat menunjukkan komitmen yang tinggi terhadap pekerjaan, karena mereka masih lebih mengutamakan urusan di luar kantor yang bersifat pribadi. Pegawai tidak dapat berkonsentrasi dengan pekerjaan juga urusan pribadi belum selesai, sehingga kurang mendukung terhadap implementasi sistem transaksi non tunai.

\section{Kesadaran \\ atas \\ Pentingnya}

Implementasi Kebijakan. Pegawai sebagai implementor harus menyadari secara sungguhsungguh bahwa maksud yang terkandung dalam suatu kebijakan adalah penting untuk diterapkan, sehingga dapat mendorong mereka untuk bersungguh-sungguh menerapkannya.

Dari uraian di atas jelaslah bahwa pegawai memahami dengan baik bahwa transaksi yang dilakukan secara tunai mengandung risiko yang tinggi terhadap penyelewenangan, karena dengan memegang uang tunai maka kesempatan untuk melakukan penyelewengan menjadi lebih besar. Pegawai menyadari bahwa transaksi non tunai menjadi salah satu cara untuk mencegah penyelewengan. Dengan demikian tingkat kesadaran pegawai terhadap pentingnya pelaksanaan transaksi non tunai cukup mendukungn dalam proses implementasi sistem transaksi non tunai.

Struktur Birokrasi. Struktur birokrasi terdiri dari unit-unit organisasi, struktur dan keterkaitan atau hubungan antara fungsi, yang secara jelas dapat dilihat dalam struktur organisasi dan uraian tugasnya. Edward III dalam Widodo (2010:106) menyatakan bahwa implementasi kebijakan bisa jadi masih belum efektif karena ketidakefisienan struktur birokrasi". Struktur birokasi ini menurut Edward III dalam Widodo (2010:106) mencangkup aspek- aspek seperti struktur birokrasi, pembagian kewenangan, hubungan antara unit-unit organnisasi dan sebagainya.

Indikator yang digunakan untuk mengetahui struktur birokrasi tersebut adalah: pembagian tugas, koordinasi, dan prosedur transaksi.

Pembagian Tugas, Pentingnya pembagian tugas dalam struktur organisasi dalam implementasi sistem transaksi non tunai akan memperjelas siapa yang bertanggungjawab melaksanakan dan mengotorisasi setiap transaksi penerimaan pendapatan dan pembayaran belanja.

Dari uraian di atas jelaslah bahwa pembagian tugas dalam organisasi telah dilakukan dengan jelas dan semua pegawai telah mengetahui tugas serta telah diberi pedoman mengenai cara melakukan tugas tersebut. Dengan demikian bahwa pembagian tugas dalam organisasi telah mendukung proses implementasi sistem transaksi non tunai.

Edward III dalam Widodo (2010), mengatakan bahwa struktur birokrasi yang terfragmentasi (terpecah-pecah atau tersebar red.) dapat meningkatkan gagalnya komunikasi, karena kesempatan untuk instruksinya terdistorsi sangat besar. Semakin terdistorsi dalam pelaksanaan kebijakan, semakin membutuhkan koordinasi yang intensif

Koordinasi yang baik dapat mengendalikan semua proses yang dilakukan secara terpisah agar menjadi lebih terpadu. Koordinasi kegaitan dalam proses implementasi sistem transaksi non tunai juga penting, agar semua pegawai melakukan segala upaya untuk mewujudkan pelaksanaan transaksi non tunai.

Fungsi koordinasi telah dilaksanakan dengan baik, karena semua pegawai mematuhi prosedur transaksi yang secara otomatis telah mengkoordinasikan semua kegiatan menjadi lebih terpadu dalam mencapai tujuan. Dengan demikian fungsi koordinasi dalam instansi tersebut telah dilaksanakan dengan baik untuk mendukung proses implementasi sistem transaksi non tunai di Kabupaten Dairi

Prosedur transaksi sangat penting dalam melakukan transaksi keuangan, sehingga setiap orang dapat mengetahui dengan jelas bagaimana proses administrasi dilakukan agar transaksi dapat dilakukan dengan baik. Harus terdapat panduan khusus yang berisi tentang bagaimana transaksi dilakukan, dan perlu pula diketahui sejauhmana prosedur tersebut dapat mendukung pelaksanaan transaksi secara non tunai.

Badan Keuangan dan Aset Daerah Kabupaten Dairi telah menyediakan panduan dalam melakukan transaksi keuangan, dimana 
semua pegawai dan pihak lain dapat mempelajarinya. Dengan demikian setiap orang yang berkentingan telah dapat mengetahui prosedur transaksi penerimaan pendapatan dan pembayaran belanja.

Faktor Kendala Dalam Penerapan Sistem Transaksi Non Tunai Dalam Pengelolaan Keuangan Daerah pada Badan Keuangan dan Aset Daerah Kabupaten Dairi

Kondisi Lapangan Yang Kurang

Mendukung. Atasan belum dapat memberi penyelesaian terhadap setiap kendala yang dihadapi dalam penerapan transaksi non tunai sebagaimana dalam Perbup Dairi No. 43 Tahun 2020 karena memang terdapat banyak kondisi lapangan yang belum sesuai dengan pelaksanaan transaksi secara non tunai. Penyelesaian terhadap faktor kendala tersebut belum dapat dilakukan dengan segera, sehingga menurut hasil wawancara bahwa implementasi harus dilakukan secara bertahap tanpa harus mengganggu proses transaksi keuangan. Untuk mengatasi permasalahan tersebut sebaiknya Badan Keuangan dan Aset Daerah Kabupaten Dairi segera membuat persiapan yang matang dengan menyediakan berbagai fasilitas yang dibutuhkan dalam penerapan transaksi non tunai, proses transaksi dapat benar-benar dilaksanakan.

Kompetensi Pegawai. Berdasarkan hasil wawancara bahwa pegawai pada Badan Keuangan dan Aset Daerah Kabupaten Dairi masih kurang mampu menangani proses transaksi secara non tunai, dimana sebagian besar pengalaman pegawai dalam bertransaksi adalah secara tunai. Dengan demikian bahwa kompetensi pegawai dalam penanganan proses transaksi secara non tunai belum memadai untuk mendukung implementasi sistem transaksi non tunai. Disamping itu, pegawai kurang berkomitmen untuk mengutamakan pekerjaan dibanding kepentingan organisasi, sehingga kurang mendukung dalam implementasi sistem transaksi non tunai. Untuk mengatasi kendala tersebut maka perlu dilakukan pelatihan yang memadai kepada pegawai agar lebih mampu dalam menangani transaksi yang dilakukan secara tunai. Pimpinan juga perlu membuat penekanan agar pegawai lebih mengutamakan pekerjaan dibanding kepentingan pribadi (keluarga).

Sistem Informasi. Sistem informasi pada Badan Keuangan dan Aset Daerah Kabupaten
Dairi belum dapat mendukung implementasi sistem transaksi non tunai. Berdasarkan hasil wawancara bahwa sistem informasi tidak dapat menyediakan lebih awal informasi mengenai berapa jumlah pembayaran atas suatu jenis belanja, sehingga baru diketahui setelah adanya realisasi belanja. Demikian juga dengan penerimaan pendapatan tidak dapat diketahui lebih awal mengenai jumlah yang diterima, sehingga persiapan transaksi secara non tunai, khususnya dengan perorangan sulit dilakukan.

Disamping itu sistem penanganan transaksi untuk wajib pajak wajib pajak perorangan, seperti pajak kenderaan dan pajak bumi dan bangunan masih dilakukan secara konvensional, dimana masyarakat harus datang ke kantor pembayaran pajak, kemudian mengikuti prosedur yang telah ditetapkan, mulai dari pengisian formulir hingga pembayaran ke loket pembayaran secara tunai. Pembayaran non tunai oleh wajib pajak tersebut belum dapat dilakukan karena sistemnya belum tersedia.

Oleh karena itu, untuk mengatasi kendala tersebut maka sebaiknya Badan Keuangan dan Aset Daerah Kabupaten Dairi melakukan peyesuaian terhadap sistem informasinya, khususnya sistem informasi yang berhubungan dengan transaksi keuangan, sehingga dapat diaplikasikan untuk penerimaan pendapatan dan pembayaran belanja.

Program Pelatihan. Program pelatihan kepada pegawai untuk menangani transaksi secara non tunai telah dilaksanakan, tetapi program tersebut belum memadai karena peralatan yang tersedia khususnya untuk melakukan praktek sangat terbatas. Menurut hasil wawancara bahwa program pelatihan masih perlu pengembangan sehingga benarbenar dapat menghasilkan pegawai yang terampil sesuai dengan kebutuhan. Oleh karena itu untuk mengatasi kendala tersebut perlu dilakukan pelatihan yang lebih memadai, yaitu dengan cara menyediakan peralatan yang memadai serta instruktur yang benar-benar memahami pelaksanaan transaksi secara non tunai.

Ketersediaan Dana. Hasil wawancara menunjukkan bahwa sumber daya finansial yang dibutuhkan dalam proses implementasi transaksi non tunai belum dapat tersedia sesuai kebutuhan, karena jumlah kebutuhan cukup besar sehingga tidak dapat dipenuhi dalam satu 
tahun anggaran. Penyediaan anggaran untuk implementasi kebijakan tersebut akan dilakukan secara bertahap sehingga tidak membebani anggaran tahunan.

Tetapi menurut penulis bahwa penyediaan anggaran untuk mendukung implementasi sistem transaksi non tunai sebaiknya dilakukan segera, karena penerapan kebijakan tersebut akan segera mendapat umpan balik dari kebocoran anggaran yang semakin sedikit. Tujuan utama pelaksanaan transaksi non tunai adalah untuk mencegah penyelengan yang jumlah setiap tahun tergolong cukup besar. Jika bocoran anggaran dari penyelewengan dapat dihindari, maka hal tersebut akan dapat menutupi alokasi dana yang digunakan untuk implementasi transaksi non tunai sebagaimana diatur dalam Perbup Dairi No. 43 Tahun 2020.

\section{SIMPULAN}

Badan Keuangan dan Aset Daerah Kabupaten Dairi belum sepenuhnya dapat menerapkan transaksi keuangan secara non tunai terhadap penerimaan pendapatan dan pengeluaran belanja sebagaimana ditetapkan dalam Perbup Dairi No. 43 Tahun 2020. Kendala yang dihadapi dalam penerapan atau implementasi transaksi belum dapat diatasi, karena memang terdapat banyak kondisi lapangan yang belum sesuai dengan pelaksanaan transaksi secara non tunai. Pegawai masih kurang mampu menangani proses transaksi secara non tunai, sementara program pelatihan belum memadai karena peralatan yang tersedia khususnya untuk melakukan praktek sangat terbatas. Disamping itu, pegawai kurang berkomitmen untuk mengutamakan pekerjaan dibanding kepentingan organisasi, sehingga kurang mendukung dalam implementasi sistem transaksi non tunai. Sistem informasi belum dapat mendukung penerapan (implementasi) sistem transaksi non tunai. Sistem informasi tidak dapat menyediakan lebih awal informasi mengenai berapa jumlah pembayaran atas suatu jenis belanja. Sementara penerimaan pendapatan dari masyarakat umum sebagian besar masih dilakukan dengan sistem konvensional. Sumber daya finansial yang dibutuhkan dalam proses implementasi transaksi non tunai belum dapat tersedia sesuai kebutuhan, karena jumlah kebutuhan cukup besar sehingga tidak dapat dipenuhi dalam satu tahun anggaran.

\section{DAFTAR PUSTAKA}

Abdullah, R. (2015). Pelaksanaan Otonomi Luas dengan Pemilihan Kepala Daerah Secara Langsung. Jakarta: Raja Grafindo Persada.

Ade dan Edia. (2013). Sistem Pembayaran Kredit. Jakarta: Bumi Aksara.

Hakim, M., Kusmanto, H., \& Isnaini, I. (2019). Implementasi Kebijakan Peraturan Kepala Badan Pengawasan Keuangan dan Pembangunan Republik Indonesia Nomor 6 Tahun 2015. Strukturasi: Jurnal Ilmiah Magister Administrasi Publik, 1(2), 131-137

Hakim, M., Kusmanto, H., \& Isnaini, I. (2019). Implementasi Kebijakan Peraturan Kepala Badan Pengawasan Keuangan dan Pembangunan Republik Indonesia Nomor 6 Tahun 2015. Strukturasi: Jurnal Ilmiah Magister Administrasi Publik, 1(2), 131-137

Hati, H. (2012). Pembayaran Secara Kredit. Jakarta: Salemba Empat.

Hotang, N., Munte, R., \& Simanjuntak, S. (2020). Pengaruh Pihak Ketiga, Biaya Operasional Pendapatan Operasional dan Kredit terhadap Kinerja Keuangan pada Sektor Perbankan di Bursa Efek Indonesia. Journal of Education, Humaniora and Social Sciences (JEHSS), 3(2), 538-543.

doi:https://doi.org/10.34007/jehss.v3i2.358

https://kaltimprov.go.id/berita/transaksi-nontunai-segera-berlaku-di-kaltim, diakses pada tanggal 15 Januari 2021.

https://regional.kompas.com/read/2018/12/05/ /sebanyak-35-pemda-di-jawa-tengahsepakat-gunakan-transaksi-non-tunai?, diakses pada tanggal 15 Januari 2021

Instruksi Bupati Nomor 188.05/0910 pada tahun 2019 tentang Implementasi Transaksi Non Tunai di Lingkungan Pemerintah Kabupaten Dairi

Instruksi Presiden (Inpres) Nomor 10 Tahun 2016 tentang Aksi Pencegahan Dan Pemberantasan Korupsi

Ketike, R., Harahap, R., \& Siregar, N. (2021). Analisis Kinerja Dinas Pengelolaan Keuangan Daerah Di Bidang Pendapatan Pada Kabupaten Gayo Lues. Strukturasi: Jurnal Ilmiah Magister Administrasi Publik, 3(1), 99-117. doi:https://doi.org/10.31289/strukturasi.v3 i1.726

Ketike, R., Harahap, R., \& Siregar, N. (2021). Analisis Kinerja Dinas Pengelolaan Keuangan Daerah Di Bidang Pendapatan Pada Kabupaten Gayo Lues. Strukturasi: Jurnal Ilmiah Magister Administrasi Publik, 3(1), 99-117. doi:https://doi.org/10.31289/strukturasi.v3 i1.726 
Lumbantoruan, R., Agustin, S., Susanti, S., \& Sari, I. (2021). Pengaruh Profitabilitas, Kinerja Keuangan, Ukuran Perusahaan dan Solvabilitas terhadap Pertumbuhan Laba. Journal of Education, Humaniora and Social Sciences (JEHSS), 4(1), 442-449. doi:https://doi.org/10.34007/jehss.v4i1.674

Miftahuddin. (2019). Perbandingan Konsep Keuangan pada Bank Syariah dan Bank Konvensional. Journal of Education, Humaniora and Social Sciences (JEHSS). 2 (2): 213-228.

Pasi, N., Abdul K., Isnaini, (2016), Implementasi Sistem Informasi Manajemen Daerah Keuangan Berbasis Akrual pada Pemerintah Kebupaten Dairi, Jurnal Administrasi Publik : Public Administration Journal : Public Admnistration Journal, 7 (1): 49-63

Poedjianto, A., Warjio, W., \& Isnaini, I. (2019). Evaluasi Penatausahaan Barang Milik Daerah di Badan Pengelolaan Keuangan Kabupaten Aceh Singkil. Strukturasi: Jurnal Ilmiah Magister Administrasi Publik, 1(1), 43-51.

Poedjianto, A., Warjio, W., \& Isnaini, I. (2019). Evaluasi Penatausahaan Barang Milik Daerah di Badan Pengelolaan Keuangan Kabupaten Aceh Singkil. Strukturasi: Jurnal Ilmiah Magister Administrasi Publik, 1(1), 43-51.

Rivan, A., \& Maksum, I. (2019). Penerapan Sistem Keuangan Desa (siskeudes) dalam Pengelolaan Keuangan Desa. Jurnal Administrasi Publik : Public Administration Journal, 9(2), 92-100. doi:https://doi.org/10.31289/jap.v9i2.2487
Silalahi, B., Sihombing, M., \& Isnaini, I. (2021). Analisis Implementasi Pola Pengelolaan Keuangan Badan Layanan Umum Daerah (BLUD) Pada Rumah Sakit Umum Daerah (RSUD) Dr. RM. Djoelham Binjai. Strukturasi: Jurnal Ilmiah Magister Administrasi Publik, $3(1)$, 1-13. doi:https://doi.org/10.31289/strukturasi.v3 i1.518

Silalahi, B., Sihombing, M., \& Isnaini, I. (2021). Analisis Implementasi Pola Pengelolaan Keuangan Badan Layanan Umum Daerah (BLUD) Pada Rumah Sakit Umum Daerah (RSUD) Dr. RM. Djoelham Binjai. Strukturasi: Jurnal Ilmiah Magister Administrasi Publik, 3(1), 1-13. doi:https://doi.org/10.31289/strukturasi.v3 i1.518

Sitohang, A., \& Wulandari, B. (2020). Pengaruh Current Ratio, Debt To Equity Ratio, Earning Per Share, terhadap Kinerja Keuangan. Journal of Education, Humaniora and Social Sciences (JEHSS), 3(2), 577-585. doi:https://doi.org/10.34007/jehss.v3i2.361

Sugiyono. (2016). Metode Penelitian Kuantitatif, Kualitatif dan R \& D. Bandung: Alfabeta.

Surat Edaran Menteri Dalam Negeri Nomor 910/1867/SJ tentang Implementasi Transaksi Non Tunai pada Pemerintah Daerah Kabupaten/Kota

Suyatno, B. (2010). Metode Penelitian Kualitatif. Jakarta: Masmedia. 